\title{
Parameters for neodymium-YAG laser trabeculotomy: an in-vitro study
}

\author{
GORDON N DUTTON,' SOPHIA A CAMERON,' DONALD ALLAN, ${ }^{2}$ \\ AND RAVI THOMAS ${ }^{3}$
}

From the 'Tennent Institute of Ophthalmology, University of Glasgow, Glasgow; the ${ }^{2}$ West of Scotland Health Boards, Department of Clinical Physics, and Bio-Engineering, Glasgow; and ${ }^{3}$ the Christian Medical College, Vellore, India

SUmmary A Biophysic Médical Nanolas Q-Switched pulsed neodymium-YAG laser has been used to produce lesions in human trabecular meshwork in vitro. Sectors of corneoscleral tissue containing trabecular meshwork were suspended in a waterbath which had had a Trokel gonioscopic contact lens mounted into one side by means of a watertight seal. The laser was used to produce lesions in the trabecular meshwork on either side of each specimen. The energy levels delivered ranged from 0.5 to $7.0 \mathrm{~mJ}$, and convergence angles of $10^{\circ}$ and $18^{\circ}$ were employed. The energy levels required to produce discrete lesions into the canal of Schlemm without perforating the underlying sclera were $3 \cdot 0-5 \cdot 0 \mathrm{~mJ}$ at the $10^{\circ}$ convergence angle and $4 \cdot 0-6.0 \mathrm{~mJ}$ at the $18^{\circ}$ convergence angle setting. It is recommended that such data be determined for each type of laser prior to attempting short-pulsed laser internal trabeculotomy in patients with glaucoma.

The primary therapeutic endeavour in the management of chronic open angle glaucoma is the reduction of intraocular pressure. The greatest resistance to outflow of aqueous from the eye is provided by the trabecular meshwork. 'Surgical procedures have thus been designed to bypass or diminish this resistance either internally by means of trabeculotomy ${ }^{2}$ or externally by trabeculectomy. ${ }^{34}$

It was initially expected that the argon laser would provide an effective means of producing a fistula between the anterior chamber and the canal of Schlemm, ${ }^{5}$ but these hopes were not realised because the scarring engendered by such treatment had the reverse effect and indeed provided the basis for experimental models of glaucoma. ${ }^{6}$ Argon laser trabeculoplasty, on the other hand, is thought to reduce intraocular pressure secondary to widening of the trabecular interstices between the focal scars caused by the laser applications. ${ }^{\text {? }}$

Recent clinical studies have indicated that shortpulsed laser trabeculotomy may effectively reduce intraocular pressure in patients with glaucoma, ${ }^{x-12}$ though the potential efficacy of such treatment has Correspondence to Gordon $\mathrm{N}$ Dutton, Tennent Institute of Ophthalmology, Western Infirmary, Glasgow G11 6NT been questioned. ${ }^{1314}$ It is clear from the results of the early experimental work with the argon laser that, if a reduction in intraocular pressure is to be sustained, scarring and fibrosis of the trabecular meshwork must be avoided. To this end extensive experimental work with short-pulsed lasers has been carried out and reported in which the primary purpose has been to produce a 'clean' fistula between the anterior chamber and the canal of Schlemm. ${ }^{1418}$

The efficacy and safety of the pulsed neodymiumYAG laser as a means of producing photodisruption in the eye has been established, ${ }^{1920}$ and a wide range of such apparatus is marketed. Some laser manufacturers provide recommendations which indicate that their apparatus can effectively be used to produce an internal 'laser trabeculotomy'. However, such recommendations appear to be based on little if any experimental evidence. Indeed, the application of pulsed lasers for the treatment of open angle glaucoma is deemed to be solely investigational in the United States. ${ }^{21}$ The present study was conducted to establish whether such apparatus can effectively be used to produce a fistula into the canal of Schlemm in vitro and to establish the operating criteria required to achieve this end. 


\section{Materials and methods}

The laser apparatus employed comprised a Biophysic Médical Nanolas Q-switched short-pulsed neodymium-YAG laser.

Human trabecular tissue was prepared from a donor eye from a 64-year-old male who had not suffered antecedent ocular disease. The eye was fixed in $3 \%$ cacodylate buffered glutaraldehyde, and $2 \mathrm{~mm}$ wide radial segments of corneoscleral tissue containing the trabecular meshwork were prepared. The ciliary body and iris tissue were removed by sharp dissection.

A small plastic waterbath was prepared and a Trokel gonioscopic lens (Ocular Instruments Inc.)

Table 1 Relates the convergence angles and energy levels delivered by the $Q$-switched neodymium-YAG laser to the characteristics and extent of the lesions produced in the trabecular meshwork

\begin{tabular}{|c|c|c|c|c|c|c|}
\hline \multicolumn{7}{|c|}{ Convergence angle of $10^{\circ}$} \\
\hline \multirow[t]{2}{*}{$\begin{array}{l}\text { Speci- } \\
\text { men }\end{array}$} & \multirow{2}{*}{$\begin{array}{l}\text { Energy } \\
\text { delivere } \\
(\mathrm{mJ})\end{array}$} & \multirow{2}{*}{$\begin{array}{l}\text { Grade of } \\
\text { d lesion } \\
\text { pro- } \\
\text { duced* }^{*}\end{array}$} & \multicolumn{2}{|c|}{$\begin{array}{l}\text { Surface diameter } \\
\text { of lesion }(\mu \mathrm{m})\end{array}$} & \multicolumn{2}{|c|}{$\begin{array}{l}\text { Deep diameter } \\
\text { of lesion }(\mu m)\end{array}$} \\
\hline & & & mean & $\begin{array}{l}\text { Standard } \\
\text { deviation }\end{array}$ & Mean & $\begin{array}{l}\text { Standard } \\
\text { deviation }\end{array}$ \\
\hline $1 \mathrm{~L} \dagger$ & 0.5 & 1 & 349 & 27 & - & - \\
\hline $\mathbf{R}$ & 0.5 & 2 & 94 & 2 & 54 & 13 \\
\hline $2 \mathrm{~L}$ & $1 \cdot 0$ & 2 & 139 & 15 & 99 & 20 \\
\hline $\mathbf{R}$ & $1 \cdot 0$ & 2 & 85 & 2 & 73 & 7 \\
\hline $3 \mathrm{~L}$ & $2 \cdot 0$ & 2 & 121 & 4 & 59 & 4 \\
\hline $\mathbf{R}$ & $2 \cdot 0$ & 2 & 73 & 7 & 54 & 13 \\
\hline $4 \mathrm{~L}$ & $3 \cdot 0$ & 3 & 223 & 34 & 158 & 20 \\
\hline $\mathbf{R}$ & $3 \cdot 0$ & 4 & 210 & 24 & 125 & 2 \\
\hline $5 \mathrm{~L}$ & $4 \cdot 0$ & 4 & 311 & 27 & 230 & 0 \\
\hline $\mathbf{R}$ & $4 \cdot 0$ & 4 & 315 & 21 & 243 & 0 \\
\hline $6 \mathrm{~L}$ & $5 \cdot 0$ & 4 & 313 & 9 & 167 & 4 \\
\hline $\mathbf{R}$ & $5 \cdot 0$ & 1 & 297 & 45 & - & - \\
\hline $7 \mathrm{~L}$ & 6.0 & 5 & 177 & 8 & 92 & 0 \\
\hline $\mathbf{R}$ & $6 \cdot 0$ & 5 & 272 & 4 & 113 & 12 \\
\hline \multicolumn{7}{|c|}{ Convergence angle of $18^{\circ}$} \\
\hline $8 \mathrm{~L}$ & 0.5 & 1 & 62 & 0 & - & - \\
\hline $\mathbf{R}$ & 0.5 & 2 & 262 & 15 & 105 & 4 \\
\hline $9 \mathrm{~L}$ & $1 \cdot 0$ & 0 & - & - & - & - \\
\hline $\mathbf{R}$ & $1 \cdot 0$ & 0 & - & - & - & - \\
\hline $10 \mathrm{~L}$ & $2 \cdot 0$ & 0 & - & - & - & - \\
\hline $\mathbf{R}$ & $2 \cdot 0$ & 0 & - & - & - & - \\
\hline $11 \mathrm{~L}$ & $3 \cdot 0$ & 1 & 195 & 4 & 71 & 21 \\
\hline $\mathbf{R}$ & $3 \cdot 0$ & 1 & 149 & 24 & 79 & 4 \\
\hline $12 \mathrm{~L}$ & $4 \cdot 0$ & 0 & - & - & - & - \\
\hline $\mathbf{R}$ & $4 \cdot 0$ & 3 & 131 & 20 & 72 & 22 \\
\hline $13 \mathrm{~L}$ & $5 \cdot 0$ & 2 & 221 & 25 & 121 & 22 \\
\hline $\mathbf{R}$ & $5 \cdot 0$ & 4 & 264 & 31 & 239 & 8 \\
\hline $14 \mathrm{~L}$ & $6 \cdot 0$ & 4 & 336 & 4 & 172 & 16 \\
\hline $\mathbf{R}$ & $6 \cdot 0$ & 4 & 262 & 8 & 218 & 18 \\
\hline $15 \mathrm{~L}$ & $7 \cdot 0$ & 4 & 256 & 13 & 247 & 15 \\
\hline $\mathbf{R}$ & $7 \cdot 0$ & 5 & 324 & 37 & 130 & 41 \\
\hline
\end{tabular}

${ }^{*}$ See Fig. 1 for classification $†$ Side of specimen. The means and standard deviations of measurements were taken by three independent observers. (compatible with pulsed neodymium-YAG laser use) was mounted with a watertight seal into one wall. The bath was filled with normal saline. Each specimen was mounted on cardboard and was sequentially immersed in the bath in such a manner that the trabecular meshwork could be clearly viewed through the centre of the Trokel lens by means of the laser slit-lamp microscope.

The laser was adjusted to each of the settings indicated in Table 1, and for each setting the laser was aimed and fired twice at the posterior trabecular meshwork at either side of each wedge shaped specimen. In each case the aiming beam was focused on the surface of the trabecular meshwork close to the cut edge of the specimen. This technique permitted subsequent evaluation of the lesions produced, in both the transverse and vertical dimensions.

Each specimen was reimmersed in $0.2 \mathrm{M}$ cacodylate buffer and was subsequently prepared for scanning electron microscopy (Jeol JSMT200) by critical point drying and gold coating. The transverse dimensions of the lesions produced were measured from the electron micrographs by three observers and the mean and standard deviations of these triplicate recordings determined. The measurements taken comprised the transverse diameter of each lesion at the surface of the trabecular meshwork and the minimum internal transverse diameter. In some cases a symmetrical focus of compression of the trabecular beams was produced and only the surface measurement thus recorded. As considerable variation in the observers' estimates of the vertical dimensions of the trabecular meshwork was found, the vertical extent of the lesions produced was not measured but graded according to the legend to Fig. 1, in preference to using quantitative but imprecise measurements.

\section{Results}

The dimensions of the lesions produced in the trabecular meshwork in relation to the energy levels and convergence angles employed are shown in Table 1. The extent of the lesions produced in the trabecular meshwork was dependent upon the energy levels used. In most cases at low energy levels little or no effect was seen, the least observable disturbance being a focal area of apparent compression of the surface of the trabecular meshwork (Fig. 1A).

As the energy level was increased, a concomitant increase in the size and depth of the lesions produced was observed (Fig. 1B-F). At the $10^{\circ}$ convergence angle setting lower energy levels were required to produce similar lesions to those obtained at the $18^{\circ}$ convergence angle setting. 


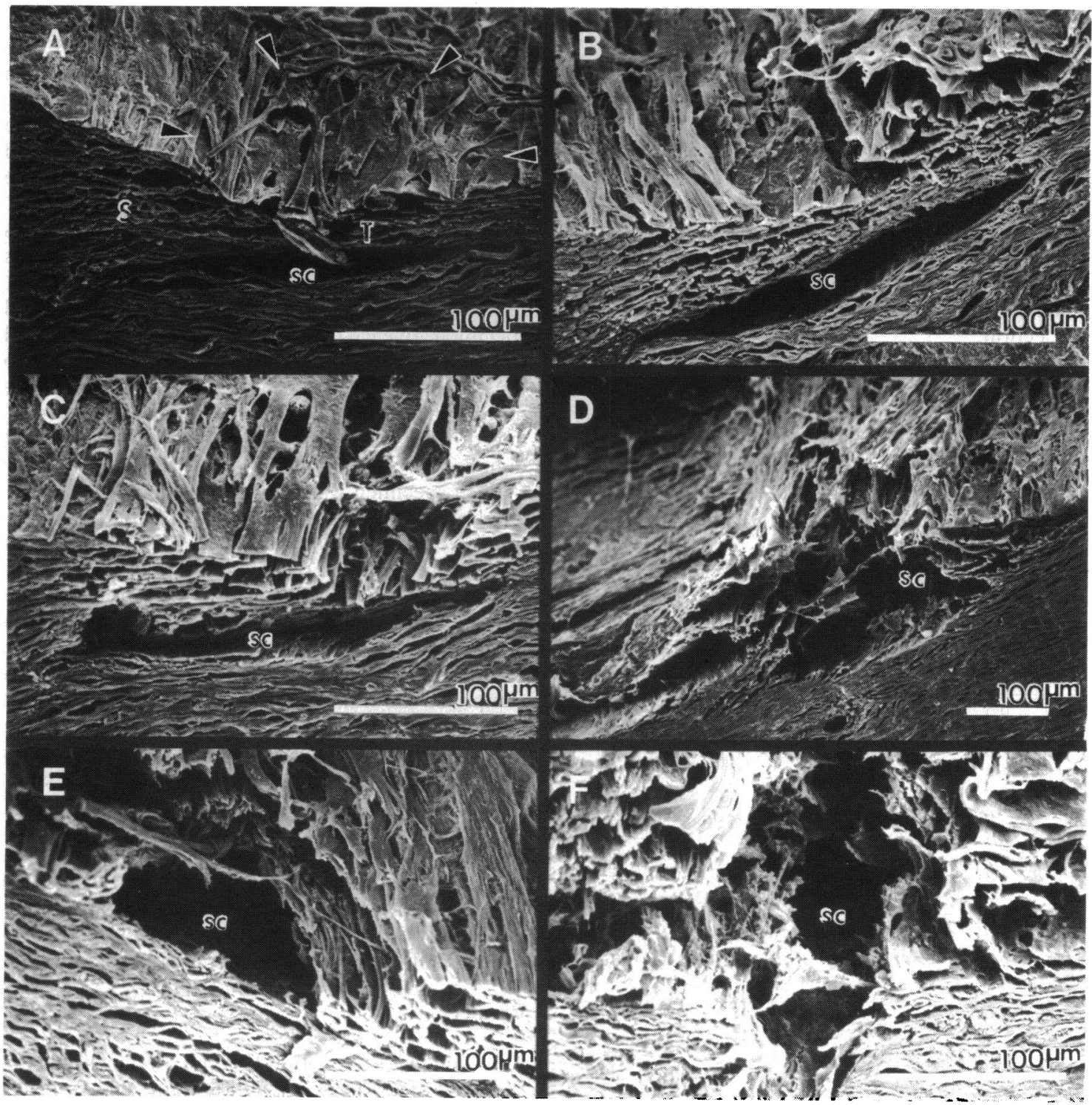

Fig. 1 Scanning electron micrographs of lesions produced in the trabecular meshwork by means of a pulsed neodymiumYAG laser (Grade $0=$ no lesion produced). A: Grade I=Superficial trabecular compression (arrowheads) with minimal disruption. B: Grade 2=Superficial trabecular disruption with no penetration into the canal of Schlemm. C: Grade $2=$ Discrete focus of trabecular disruption with no penetration into the canal of Schlemm. D: Grade $3=$ Trabecular perforation through to the canal of Schlemm with slight disruption of the outer wall. E: Grade 4=Broad perforation through to the canal of Schlemm with limited disruption of the outer wall. F: Grade $5=$ Extensive disruption of the trabecular meshwork in which the perforation has extended through the outer wall of the canal of Schlemm into the underlying sclera. $\mathrm{S}=$ scleral spur. $\mathrm{T}=$ trabecular meshwork. $\mathrm{sc}=$ Canal of Schlemm .

Although at either convergence angle setting the trend was for wider lesions to be produced, at higher energy settings there was no linear relationship between the two parameters of lesion width and energy delivered. However, with regard to the qualitative assessment as to the depth of the lesion produced there was a much clearer association between penetration and energy delivered. 
The minimum energy settings which were found to produce a hole into the canal of Schlemm, with minimal damage to the outer wall of the canal were $3 \mathrm{~mJ}$ at the $10^{\circ}$ convergence angle and $4 \mathrm{~mJ}$ at the $18^{\circ}$ convergence angle. The gradation of tissue damage produced increased more gradually as the energy level was increased with the convergence angle of $10^{\circ}$ than with the convergence angle of $18^{\circ}$.

\section{Discussion}

Clinical studies have indicated that a significant reduction in intraocular pressure can be produced in patients with chronic open angle glaucoma with raised intraocular pressure, by firing a short-pulsed laser at the trabecular meshwork. ${ }^{-12}$ Although initial reports have mostly been encouraging, the long term efficacy of such treatment has yet to be established. Moreover, each group of workers has studied different types of cases and has employed differing regimens of treatment. In theory, if a pulsed laser can be applied in such a way as to produce a fistula into the canal of Schlemm without either disrupting adjacent trabecular tissues or producing a hole through into the sclera, the likelihood of subsequent fibrosis and fistula closure may be diminished. ${ }^{17}$ Recent work conducted with this end in mind has established that the exact operating criteria for the Qswitched neodymium-YAG laser must be precise..$^{178}$ The results of the present study indicate that analogous constraints apply to commercially available apparatus. If the energy level employed is too low, then no fistula into the canal is produced. Conversely, at high energy levels severe disruption of the trabecular meshwork and the canal of Schlemm is seen, with perforation into the underlying sclera. It is also evident that the convergence angle employed is a major determinant as to the nature and extent of the tissue damage produced. The Trokel lens has a convex surface and thus increases the convergence angle of the laser beam within the eye, and this must be borne in mind when interpreting the results described here.

The differences between the laser system employed for the present study and the system used in previous investigations in the same department ${ }^{1718}$ hinder precise comparisons of the results. In the previous studies energy levels of greater than $14 \mathrm{~mJ}$ were required to produce fistulae into the canal of Schlemm with a laser beam convergence angle of $6^{\circ} . .^{17}$ If similar mode structures of the laser beam are assumed for the present study, energy settings between 3 and $4 \mathrm{~mJ}$ at $10^{\circ}$ and $18^{\circ}$ convergence angles provide approximately the same energy density at the focal point.

The energy density at the laser beam focus varies directly with the square of the cone angle of the convergent beam. It may thus initially appear paradoxical that higher energy levels are required for the higher $\left(18^{\circ}\right)$ convergence angle to produce the desired tissue effect. However, the narrower $10^{\circ}$ convergence angle gives rise to a greater plasma length which is presumably required to produce a hole of sufficient depth.

Before treatment of this nature can be considered as a means of reducing intraocular pressure in patients with chronic open angle glaucoma many questions remain to be answered. How many fistulae into the canal of Schlemm and of what dimensions are required to reduce the intraocular pressure $?^{22}$ What initial degree of raised intraocular pressure is required for a demonstrable reduction to be produced and sustained? Furthermore, morphological studies are required which assess the degree of replicability of the lesions produced in the trabecular meshwork for any given energy setting, as this has been shown in previous studies ${ }^{18}$ to vary considerably.

It is apparent that the optimal operating criteria required to produce a discrete and patent fistula into the canal of Schlemm are likely to vary and to be very precise. It is thus important that, unless appropriate experimental studies have been conducted, 'guidelines' as to what energy levels are required to produce an internal laser trabeculotomy should not be issued.

We thank Keeler Ltd, United Kingdom agents for Biophysic Médical, for access to the laser. The research was supported by a grant from the Scottish Hospital Endowments Research Trust. We thank Professor W S Foulds and Professor W R Lee for their advice and assistance.

\section{References}

1 Chandler PA, Grant WM. Glaucoma. 2nd ed. Philadelphia: Lea and Febiger, 1979: 77-109.

2 Smith R. A new technique for opening the canal of Schlemm. Preliminary report. BrJ Ophthalmol 1960; 44: 370-3.

3 Cairns JE. Trabeculectomy. Preliminary report of a new method. Am J Ophthalmol 1968; 66: 673-9.

4 Watson PG. Surgery of the glaucomas. Br J Ophthalmol 1972; 56: 299-318.

5 Ticho U, Cadet JC, Mahler J, Sekeles E, Bruchin A. Argon laser trabeculotomies in primates: evaluation by histological and perfusion studies. Invest Ophthalmol Vis Sci 1978; 17: 667-74.

6 March WF, Gherezghiher T, Koss M, Nordquist R. Ultrastructural and pharmacologic studies on laser-induced glaucoma in primates and rabbits. Lasers Surg Med 1984; 4: 329-35.

7 Wise JB, Witter SL. Argon laser therapy for open-angle glaucoma. Arch Ophthalmol 1979; 97: 319-22.

8 Krasnov MM. Q-switched laser goniopuncture. Arch Ophthalmol 1974; 92: 37-41.

9 Robin AL, Pollack IP. The Q-switched ruby laser in glaucoma. Ophthalmology 1984; 91: 366-72.

10 Robin AL, Pollack IP. Q-switched neodymium-YAG laser angle surgery in open-angle glaucoma. Arch Ophthalmol 1985; 103: 793-5. 
11 Schrems W, Sold J, Krieglstein GK, Leydhecker W. Zum tonographischen Wirkungsnachweis der YAG-LaserTrabekuloplastik beim chronischen Glaukom. Klin Monatsbl Augenheilkd 1985; 187: 170-2.

12 Schrems W, Glaab-Schrems E, Krieglstein GK, Leydhecker W. Zur Wirkung der Neodym-YAG-Laserbehandlung beim Offenwinkel-Glaukom. Fortschr Ophthalmol 1985; 82: 382-4.

13 Epstein DL, Melamed S, Puliafito CA, Steinert RF. Neodymium:YAG laser trabeculopuncture in open-angle glaucoma. Ophthalmology 1985; 92: 931-7.

14 Melamed S, Pei J, Puliafito CA, Epstein DL. Q-switched neodymium-YAG laser trabeculopuncture in monkeys. Arch Ophthalmol 1985; 103: 129-33.

15 van der Zypen E, Bebie H. Fankhauser F. Morphological studies about the efficiency of laser beams upon the structures of the angle of the anterior chamber. Int Ophthalmol 1979; 1,2: 1(19-22.

16 Ticho U, Mahler J, Sekeles E, et al. Low-energy trabeculotomies in primates. Exp Eye Res 1981; 33: 11-8.

17 Venkatesh S, Guthric S. Foulds WS, Lee WR, Cruickshank FR,
Bailey RT. In vitro studies with a pulsed neodymium/YAG laser. BrJ Ophthalmol 1985; 69: 86-91.

18 Venkatesh S, Lee WR, Guthrie S, et al. An in vitro morphological study of $\mathrm{Q}$-switched neodymium-YAG laser trabeculotomy. BrJ Ophthalmol 1986; 70: 89-96.

19 Aron-Rosa D, Aron J-J, Cohn HC. Use of a pulsed picosecond Nd-YAG laser in 6,664 cases. J Am Intraocul Implant Soc 1984; 10: $35-9$.

20 Fankhauser F, Lortscher H, van der Zypen E. Clinical studies on high and low power laser radiation upon some structures of the anterior and posterior segments of the eye. Int Ophthalmol 1982; 5: $15-32$.

21 Belcher CD, Mainster MA, Buzney SM. Current status of neodymium-YAG laser photodisruptors in ophthalmology: part II. Ann Ophthalmol 1983; 15: 1097-9.

22 Goldschmidt CR, Ticho U. Theoretical approach to laser trabeculotomy. Med Phys 1978; 5: 92-9.

Accepted for publication 28 October 1986. 